\title{
Involvement of Sting-Activating Cyclic Di-Nucleotides on T-Cell Differentiation and Function: An Unresolved Issue
}

\author{
Sting'i Etkinleştiren Siklik Dinükleotidlerin T Hücre Diferansiyasyonu ve Fonksiyonuna Olan \\ Etkisi: Çözülmemiş bir Sorun
}

Begüm Yıldız, İhsan Gürsel

Department of Molecular Biology and Genetics, Thorlab, Therapeutic Oligonucleotide Research Laboratory, Bilkent University, Ankara, Turkey

\section{Correspondence:}

İhsan Gürsel, MD.

Bilkent Üniversitesi, Thorlab, Moleküler Biyoloji ve Genetik Bölümü, Fen Fakültesi, 06800 Bilkent, Ankara, Turkey

Tel: +90 312 - 2902408

e-mail: ihsangursel@bilkent.edu.tr

(C2016 Turkish Journal of Immunology. All rights reserved.

doi: $10.5606 / \mathrm{tji} .2016 .513$

Received: October 26, 2016 Accepted: January 05, 2017
STING is the pivotal mediator for the recognition of host and pathogenic cytosolic dsDNA as well as cyclic di-nucleotide metabolites from microbes. Studies demonstrated that DNA released from cancerous cells are internalized by innate immune cells such as macrophages and dendritic cells in tumor microenvironment and trigger the production of interferon beta and other pro-inflammatory cytokines including interleukin 6, tumor necrosis factor alpha, and interleukin 12 through STING triggered signaling pathway. Later, these cytokines increase the cytotoxic activity of CD8+ T-cells by increasing the production of interferon gamma. This review discusses the importance of the involvement of STING during the establishment of immunity against intracellular pathogens and its direct effect on T-cells.

Keywords: Adjuvant; cGAMP; immune response; STING; T-lymphocytes.

STING (Stimulator of interferon genes), hem patojen ve konağın kendi sitozolik çift sarmallı DNA (dsDNA)'sına hem de mikrop kaynaklı siklik di-nükleotidlerin tanınmasında önemli bir mediyatördür. Çalışmalar, kanser hücrelerinden salınan DNA'nın, makrofaj ve dendritik hücreler gibi doğal bağışıklık sistemi hücreleri tarafından tümör mikro çevresindeki hücrelerce alındığını göstermiştir. Bu internalizasyon STING'in tetiklediği yolak üzerinden interferon beta, interlökin 6 , tümör nekroz faktör alfa ve interlökin 12 gibi diğer pro-enflamatuar sitokinlerin salımını yönlendirir. Daha sonra bu sitokinler interferon gama üretimini artırarak CD8 ${ }^{+}$ $\mathrm{T}$ hücrelerinin sitotoksik etkinliklerini artırır. Bu derleme STING yolağının hücre içi patojenlere karşı oluşan immünitedeki rolünü ve T-hücreleri üzerine olası doğrudan etkilerini tartışmaktadır. Anahtar sözcükler: Adjuvan; cGAMP; immün cevap; STING; T lenfositleri.
The general and main goal of the immune system are to guard the body from wide range of microorganism. During recognition and elimination of microbes, the first discernment mechanism is its ability to distinguish self from non-self. This ability provides the immune system to eradicate not only microbes but also toxins and allergens. ${ }^{[1]}$ The immune system has two arms including innate and adaptive immunity. These two arms of the immune system implement the main mechanism, which is the discrimination of self from non-self to protect host from intruders and pathologic insult. The innate and adaptive immune systems are complementing each other during the combat with the insulting agent and relies on similar as well as distinct signaling mechanisms. Importantly, they differ in terms of rapidity and specificity of the response. The innate immune system is the first line of defense of the body and consists of both physical, chemical barriers and specific type of cells such as monocytes, macrophages, and neutrophils. The basic virtue of the innate immune system is an immediate defense. ${ }^{[2]}$ The cells of the innate immune system react against pathogens at the same extent no matter how many times they encounter. On the other hand, adaptive immune system possesses the antigen specific response, which establishes antigen dependent specificity by $\mathrm{T}$ - and B-lymphocytes. In other words, the hallmark of adaptive immunity is an increased response in the presence of repeated infectious and the development of memory against specific antigens. ${ }^{[3]}$ 
Innate immune system, which comprises of various types of cells including monocytes, dendritic cells, macrophages, neutrophils, basophils, eosinophils, mast cells and natural killer cells, provides the first and immediate response against pathogens. Although innate immune system does not have any capability to develop memory against specific type of antigens, the majority of infections that the host encounter are cleared by innate immune cells without any interaction with adaptive immunity. Innate immune system has three distinct phases to eliminate pathogens. In the first phases, physical barriers and soluble factors such as antimicrobial peptides or complement system are implemented for the clearance of pathogens. After releasing soluble factors upon microbes, pathogensensing mechanisms are triggered by innate immune cells and gets activated. Pathogen associated molecular patterns (PAMPs) are molecules from pathogens that are sensed by the members of the innate immune system. They are recognized by pattern recognition receptors (PRRs) including Toll-like receptors (TLRs), Nucleotide oligomerization receptors (NLRs), C-type lectin receptors (CLRs) and RIG-1 like receptors (RLRs), AIM2 like receptors (ALRs) and cytosolic DNA sensors. As a third phase, specific type of innate immune cells called antigen presenting cells (APCs) present pathogen specific antigens to $T$ lymphocytes for the expansion of antigen specific lymphocytes and long term memory. ${ }^{[4]}$

\section{PATHOGEN SENSING MECHANISMS AND CYTOSOLIC DNA SENSORS}

The pathogen sensing mechanism of innate immune system is mostly based on pattern recognition receptors (PRRs), which can identify the different part of pathogens. PRRs consist of different type of receptors including TLRs, NLRs, CLRs, RLRs, ALRs and cytosolic DNA sensors. They can be either at the cell surface or inside cell. ${ }^{[5]}$ When pathogen associated molecules are sensed by PRRs, pro-inflammatory cytokines or chemokines start to be secreted by innate immune cells by activating several signaling transduction pathways. Upon secretion of several cytokines and chemokines, other immune system members are recruited into the site of infection to strengthen the response. ${ }^{[6]}$

The recognition of pathogen-associated deoxyribonucleic acids (DNA) is the essential and spectacular mechanism by which innate immune cells detect microbes to trigger the second response for the protection. However, one of the most important criteria for this mechanism is the differentiation of selfDNA and DNA from microbes. If this differentiation mechanism is interrupted, various types of autoimmune diseases arise. This is why the molecular mechanism of DNA sensors should be investigated and understood. ${ }^{[7]}$

There are several cytosolic DNA sensors including TLRs, ALRs and other DNA sensors. However, the major difference between TLRs and other cytosolic DNA sensors is the specificity of the sequence. TLR9 only senses $\mathrm{CpG}$ motifs by inducing type I IFN response whereas other DNA sensors including AIM2, cGAS (Cyclic GMP-AMP synthase) and STING (Stimulator of interferon genes) recognize DNA in a sequenceindependent manner and provide huge amount of inflammatory cytokine secretion from innate immune cells. AIM2 is one of the cytosolic DNA sensors and leads to formation and oligomerization of the inflammasome complex by triggering caspase-1 cleavage and secretion of pro-inflammatory cytokines such as IL-1 beta and IL-18 unlike cGAS and STING. ${ }^{[8]}$

\section{STING: THE CENTRAL SENSOR FOR TYPE-I INTERFERON SIGNALING}

STING (Stimulator of interferon genes; also known as TMEM173, MPYS, MITA and ERIS) has a critical and central role as a DNA sensor since it can sense various types of pathogens such as bacteria and virus. ${ }^{[9]}$ Moreover, recent studies showed that over-expression of STING causes severe autoimmune diseases. On the other hand, other studies demonstrated that it triggers activation of the adaptive immune cells in response to DNA vaccines. ${ }^{[10]}$ Thus, understanding DNA sensing mechanism is crucial in terms of activation of innate and adaptive immune systems. STING is expressed mainly in the thymus, peripheral leukocytes, spleen, lung, heart and placenta but is poorly expressed in the brain, skeletal muscle, colon, small intestines, liver and kidney. ${ }^{[11,12]}$

cGAS is another key DNA sensor to boost both innate and adaptive immune systems in the presence of virus or bacteria. cGAS, which is an enzyme, recognizes dsDNA in cytosol in a sequence-independent manner and leads to secretion of type I interferon through STING pathway. Upon activation of cGAS by binding dsDNA, it converts cytosolic ATP and GTP to cyclic guanosine adenosine monophosphate (cGAMP). cGAMP activates STING signaling pathway by leading to type I interferon secretion. ${ }^{[13,14]}$ Beside cGAS, other cytosolic proteins including DAI, DDX41, DNA-PK, and IFI16 recognize dsDNA and activate STING pathway resulting in e production of type I interferon. ${ }^{[15]}$ Moreover, bacterial secondary metabolites such as cyclic di-GMP and cyclic di-AMP are sensed by DDX1 and STING activating signaling pathway leading to secretion of type I interferon. ${ }^{[16]}$ Previous studies claimed that, upon STING activation through cyclic di-nucleotides 
including cGAMP, c-di-GMP or c-di-AMP, other protein complexes or dsDNA, STING becomes activated and translocates from the ER. Although the exact mechanism remains unclear, Ishikawa and Barber ${ }^{[9]}$ claimed that it goes to perinuclear vesicles by recruiting TBK1. STING-TBK1 complex phosphorylates IRF3 by providing its dimerization. Phosphorylated IRF3 goes to nucleus and binds to the promoter region of interferon beta by leading production of interferon beta and other co-regulated genes. Beside IRF3, STING-TBK1 complex provides phosphorylation of STAT6 resulting in secretion of STAT6 dependent chemokines including CCL2, CCL20, and CCL26. ${ }^{[11,15]}$

Recent studies demonstrated that since STING activating cyclic di-nucleotides have an enormous potential to induce type I interferons and other inflammatory cytokines, they are of great importance against infections and cancer in terms of vaccine adjuvant therapies. ${ }^{[17-19]} \mathrm{Li}$ et al. ${ }^{[20]}$ showed that innate immune cells including macrophages and dendritic cells from cGAS deficient mice failed to produce type I interferons and other related cytokines in the presence of virus infectious. They also demonstrated that cGAMP as an adjuvant boosts antigen specific T cells activation and antibody production in vivo. Beside infections, cyclic di-nucleotides become potential adjuvant for tumor immunotherapy. The study that was conducted by Woo et al. ${ }^{[21]}$ pioneered to demonstrate the effect of STING signaling pathway in tumor microenvironment. When tumor-cell-derived DNA is released into environment, it is internalized by antigen presenting cells such as dendritic cells and trigger STING signaling pathway through cGAS-cGAMP-STING resulting in production of interferon beta and other inflammatory cytokines such as TNF- $\alpha$, IL- 6 and IL-12. These secreted cytokines provide an increase in $\mathrm{CD}^{+} \mathrm{T}$ cell priming against tumors via presenting tumor antigens. ${ }^{[21]}$ As a result, they concluded that the host STING pathway is of capital importance for the mechanism of innate immune sensing of cancers and for the mechanism of destroying tumor cells. In the light of these findings, cyclic di-nucleotides such as cGAMP as STING ligands are considered to be critical vaccine adjuvants due to enhanced $\mathrm{T}$ cell priming capacity. Other studies focused on the investigation of in vivo immunotherapeutic potential of cyclic di-nucleotides. C-di-GMP was shown to induce interferon beta together with TNF- $\alpha$, IL- 6 and IL-12 in myeloid dendritic cells, RAW cell lines, mouse splenocytes and human PBMCs. ${ }^{[22-24]}$ On the other hand, Yildiz et al. ${ }^{[25]}$ showed that when c-di-GMP complexed with the cationic peptide nona-arginine, its uptake efficiency and the vaccine adjuvant activity increased. Furthermore, they increased the immunostimulatory activity of c-di-GMP by combining with the TLR9 ligand, $\mathrm{CpG}$ oligodeoxynucleotide (CpG ODN). At the same time, another group combined $\mathrm{K} 3 \mathrm{CpG}$ and cGAMP and showed that this combination increased potency of type I adjuvant by providing a promising immunotherapeutic agent for cancer. ${ }^{[26]}$ An important new study showed that the combination of cGAMP with chemotherapeutic agent 5-FU become a novel anti-tumor agent and has broad implications in immunotherapy. ${ }^{[27]}$ As a result, cyclic di-nucleotides such as cGAMP become an important and effective vaccine adjuvant against intracellular pathogens and malignant cells. Although STING activating cyclic di-nucleotides are envisioned as novel and potent vaccine adjuvants, more thorough research is needed to unearth the mechanism of action of STING on different immune cells. Therefore, it will pave the way for the initiation of successful human trials.

\section{EFFECT OF STING ACTIVATION ON T-CELL DIFFERENTIATION AND FUNCTION: AN UNIDENTIFIED ISSUE}

The important criteria while developing vaccine adjuvants is the magnitude and quality of the immune response and its toxic side effects. To identify these, members of the both innate and adaptive immune system should be taken into account. However, previous studies merely focus on the function and effect of cGAMP in innate immune cells such as macrophages, monocytes and dendritic cells. However, to date there is no explicit study investigating the effect of STING signaling cascade on T-cells. There is only one abstract, which claims that STING deficiency increases expression of genes related with cytotoxic $\mathrm{T}$ lymphocytes.

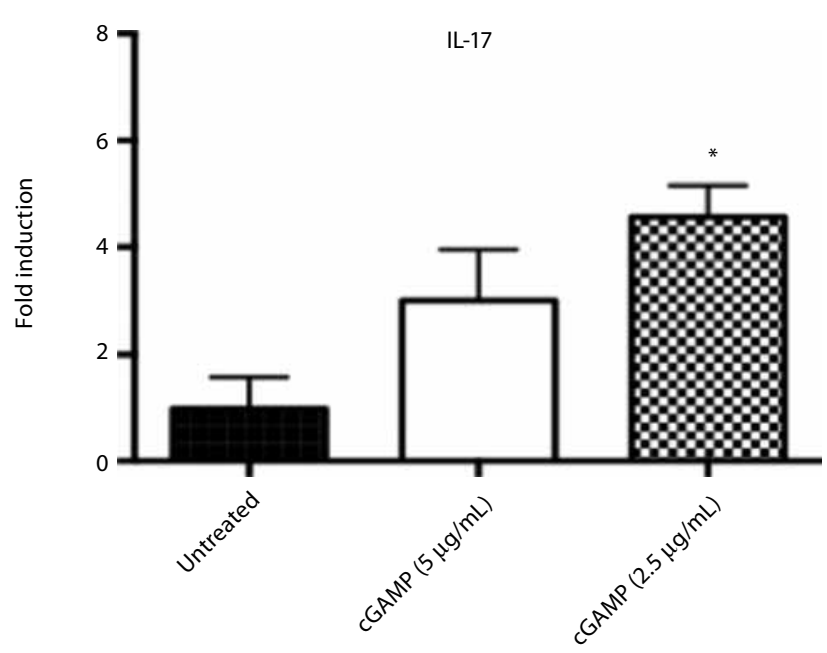

Figure 1. CGAMP induces IL-17 secretion in Pan T cells. Pan T cells were stimulated with CGAMP for 3 days and IL-17 secretions were measured by ELISA $p<0.05$ (Begum Yildiz, MSc Thesis, Bilkent University, 2016, unpublished data). cGAMP: Cyclic guanosine adenosine monophosphate. 
On the other hand, our preliminary data showed that STING activation via cGAMP induces IL-17 secretion from Pan $\mathrm{T}$ cells (Figure 1). In the light of these preliminary findings we hypothesized that STING activation may lead to regulation of the development of several $\mathrm{T}$ cell subsets and this should be investigated.

Type I interferons (IFN- $\alpha / \beta)$ play a significant role not only in protection against viral infections but also in progression of bacterial infections, cancer and autoimmunity. Beside, they behave like a bridge between innate and adaptive immunity. ${ }^{[28]}$ The activation of cytosolic receptors including TLRs, RLRs and cytosolic DNA sensors mostly result in secretion of type I interferons by inducing IRF pathway. Secretion of type I interferons enhances the activation of macrophages, B cell switching mechanism and the differentiation of helper T cells into Th1. ${ }^{[29]}$ STING is the essential mediator for the recognition of cytosolic dsDNA, which triggers the production of type I interferon via TBK1-IRF3 pathway. STING can recognize dsDNA directly or sense the cyclic dinucleotides secreted by pathogens. Beside, cytosolic ATP and GTP are converted into cGAMP upon DNA binding to cGAS enzyme and cGAMP interacts with STING and triggers the production of type I interferons, mostly IFN $-\beta .^{[9,10]}$ Since it has been shown that type I interferons are the key modulators to fight against bacterial, viral infections and malignancies, STING activating cyclic di-nucleotides such as cGAMP are thought to be effective candidates for vaccine adjuvants. Although they have an enormous potential as vaccine adjuvants, a great deal of research is needed in terms of immune response and cytotoxicity to initiate human clinical trials. ${ }^{[19]}$ Nevertheless, studies performed so far have focused on the effect and the function of STING in innate immune system.

In conclusion, while many studies focus on the effect of STING in the presence of cyclic di-nucleotides on innate immune cells such as dendritic cells and macrophages we still have limited knowledge of the effect of STING on T lymphocytes. We believe that our first preliminary data implied that it might have a role in differentiation of $\mathrm{T}$ lymphocytes. This will not only disclose the function of STING on T lymphocyte differentiation and activation, but may also contribute to the efficiency of vaccine adjuvant therapies.

\section{Declaration of conflicting interests}

The authors declared no conflicts of interest with respect to the authorship and/or publication of this article.

\section{Funding}

The authors received no financial support for the research and/or authorship of this article.

\section{REFERENCES}

1. Delves PJ, Roitt IM. The immune system. First of two parts. N Engl J Med 2000;343:37-49.

2. Parkin J, Cohen B. An overview of the immune system. Lancet 2001;357:1777-89.

3. Chaplin DD. Overview of the immune response. J Allergy Clin Immunol 2010;125:3-23.

4. Alberts B, Johnson A, Lewis J, Raff M, Roberts K, Walter P. Molecular Biology of the Cell. 4th ed. New York: Garland Science; 2002.

5. Medzhitov R, Janeway C Jr. Innate immunity. N Engl J Med 2000;343:338-44.

6. Akira S, Uematsu S, Takeuchi O. Pathogen recognition and innate immunity. Cell 2006;124:783-801.

7. Barbalat R, Ewald SE, Mouchess ML, Barton GM. Barbalat R, Ewald SE, Mouchess ML, Barton GM. Annu Rev Immunol 2011;29:185-214.

8. Bürckstümmer T, Baumann C, Blüml S, Dixit E, Dürnberger $\mathrm{G}$, Jahn H, et al. An orthogonal proteomic-genomic screen identifies AIM2 as a cytoplasmic DNA sensor for the inflammasome. Nat Immunol 2009;10:266-72.

9. Ishikawa H, Barber GN. STING is an endoplasmic reticulum adaptor that facilitates innate immune signalling. Nature 2008;455:674-8.

10. Sun W, Li Y, Chen L, Chen H, You F, Zhou X, et al. ERIS, an endoplasmic reticulum IFN stimulator, activates innate immune signaling through dimerization. Proc Natl Acad Sci U S A 2009;106:8653-8.

11. Ishikawa $H, M a Z$, Barber GN. STING regulates intracellular DNA-mediated, type I interferon-dependent innate immunity. Nature 2009;461:788-92.

12. de Almeida LA, Carvalho NB, Oliveira FS, Lacerda TL, Vasconcelos AC, Nogueira L, et al. MyD88 and STING signaling pathways are required for IRF3-mediated IFN- $\beta$ induction in response to Brucella abortus infection. PLoS One 2011;6:23135.

13. Sun L, Wu J, Du F, Chen X, Chen ZJ. Cyclic GMP-AMP synthase is a cytosolic DNA sensor that activates the type I interferon pathway. Science 2013;339:786-91.

14. Wu J, Sun L, Chen X, Du F, Shi H, Chen C, et al. Cyclic GMPAMP is an endogenous second messenger in innate immune signaling by cytosolic DNA. Science 2013;339:826-30.

15. Wu J, Chen ZJ. Innate immune sensing and signaling of cytosolic nucleic acids. Annu Rev Immunol 2014;32:461-88.

16. Danilchanka O, Mekalanos JJ. Cyclic dinucleotides and the innate immune response. Cell 2013;154:962-70.

17. Libanova R, Becker PD, Guzmán CA. Cyclic di-nucleotides: new era for small molecules as adjuvants. Microb Biotechnol 2012;5:168-76.

18. Temizoz B, Kuroda E, Ishii KJ. Vaccine adjuvants as potential cancer immunotherapeutics. Int Immunol 2016;28:329-38.

19. Dubensky TW Jr, Kanne DB, Leong ML. Rationale, progress and development of vaccines utilizing STINGactivating cyclic dinucleotide adjuvants. Ther Adv Vaccines 2013;1:131-43.

20. Li XD, Wu J, Gao D, Wang H, Sun L, Chen ZJ. Pivotal roles of cGAS-cGAMP signaling in antiviral defense and immune adjuvant effects. Science 2013;341:1390-4.

21. Woo SR, Fuertes MB, Corrales L, Spranger S, Furdyna MJ, Leung MY, et al. STING-dependent cytosolic DNA sensing mediates innate immune recognition of immunogenic tumors. 
Immunity 2014;41:830-42.

22. Karaolis DK, Means TK, Yang D, Takahashi M, Yoshimura T, Muraille E, et al. Bacterial c-di-GMP is an immunostimulatory molecule. J Immunol 2007;178:2171-81.

23. McWhirter SM, Barbalat R, Monroe KM, Fontana MF, Hyodo $\mathrm{M}$, Joncker NT, et al. A host type I interferon response is induced by cytosolic sensing of the bacterial second messenger cyclic-di-GMP. J Exp Med.2009;206:1899-911.

24. Gray PM, Forrest G, Wisniewski T, Porter G, Freed DC, DeMartino JA, et al. Evidence for cyclic diguanylate as a vaccine adjuvant with novel immunostimulatory activities. Cell Immunol 2012;278:113-9.

25. Yildiz S, Alpdundar E, Gungor B, Kahraman T, Bayyurt B, Gursel I, et al. Enhanced immunostimulatory activity of cyclic dinucleotides on mouse cells when complexed with a cell- penetrating peptide or combined with CpG. Eur J Immunol 2015;45:1170-9.

26. Temizoz B, Kuroda E, Ohata K, Jounai N, Ozasa K, Kobiyama K, et al. TLR9 and STING agonists synergistically induce innate and adaptive type-II IFN. Eur J Immunol 2015;45:1159-69.

27. Li T, Cheng H, Yuan H, Xu Q, Shu C, Zhang Y, et al. Antitumor Activity of cGAMP via Stimulation of cGAS-cGAMP-STINGIRF3 Mediated Innate Immune Response. Sci Rep 2016;6:19049.

28. Trinchieri G. Type I interferon: friend or foe? J Exp Med 2010;207:2053-63.

29. RK Subbarao Malireddi, Kanneganti TD. Role of type I interferons in inflammasome activation, cell death, and disease during microbial infection. Microbial Modulation of Host Apoptosis and Pyroptosis. Front Cell Infect Microbiol 2013;3:1-11. 